\title{
TENGGER BRANG KIDUL: \\ DIALEKTIKA KEHIDUPAN BERAGAMA PADA MASYARAKAT DESA NGADAS, KECAMATAN PONCOKUSUMO, KABUPATEN MALANG, JAWA TIMUR
}

\author{
Ni Putu Ayu Amrita Pradnyaswari \\ Jurusan Ilmu Administrasi Negara \\ Fakultas Ilmu Sosial dan Ilmu Politik Universitas Mahendradatta \\ Jl. Ken Arok No. 12, Peguyangan Denpasar
}

\begin{abstract}
Abstrak - Isu dekadensi dalam konteks toleransi antaumat beragama saat ini menjadi salah satu masalah sosial yang dihadapi bangsa Indonesia. Perbedaan agama dalam masyarakat seringkali memicu konflik dalam masyarakat, tetapi hal tersebut berbeda dengan kehidupan masyarakat Tengger Brang Kidul di Desa Ngadas, Kecamatan Poncokusumo, Kabupaten, Malang, Jawa Timur. Masyarakat Tengger di Desa Ngadas merupakan bagian masyarakat etnik Tengger yang memiliki potret kehidupan penuh toleransi antarumat beragama. Masyarakat di desa ini memiliki keunikan dari eksistensi masyarakat Tengger di daerah lain karena masyarakat setempat hidup dalam keragaman agama, yakni Buddha Jawa Sanyata, Hindu, dan Islam. Tradisi yang menjadin ruh kehidupan mereka juga memperkuat iman masyarakat dalam beragama, bermasyarakat, dan bernegara.
\end{abstract}

Kata kunci: representasi, toleransi, agama

\section{PENDAHULUAN}

Agama menurut Anselm von Feurbach (dalam Nashir, 1999:xi) merupakan kebutuhan ideal manusia sehingga agama memiliki peranan yang sangat penting dalam kehidupan manusia. Peranan agama menjadi sangat penting ketika agama telah dianut oleh kelompok-kelompok sosial manusia, yang terkait dengan berbagai kegiatan pemenuhan kebutuhan hidup manusia yang kompleks dalam masyarakat. Agama adalah seperangkat keyakinan yang sakral dan mutlak, yang mengatur hubungan manusia dengan Tuhan, hubungan manusia dengan manusia, dan hubungan manuisa dengan alam kehidupan pada umumnya di dunia ini (Nashir, 1999:ix). Agama juga merupakan suatu pedoman hidup yang memiliki manfaat, yakni (1) mendidik manusia agar mempunyai pendirian yang pasti dan terang agar tercipta manusia yang positif dan tepat, (2) mendidik manusia agar mengetahui cara mencari dan memiliki ketentraman jiwa, (3) menjadi alat untuk membebaskan manusia dari perbudakan materi, (4) mendidik manusia untuk senantiasa menegakkan kebenaran dan takut melakukan kesalahan, (5) memberikan sugesti kepada manusia agar tum- buh jiwa positif di dalam diri mereka, serta (6) mendidik orang untuk memakmurkan masyarakat dan negara (Hidayatullah, 2011:19).

Dalam terma yang lebih luas, agama tampak menjadi komponen kebudayaan publik yang semakin penting daripada sekedar kepercayaan dan praktik pribadi (Turner, 2013:1). Persentuhan agama dalam struktur sosial bukan saja melahirkan beragam corak keberagaman dalam berbagai aliran dan corak pengalaman beragama, tetapi juga membuat persentuhan saling berkaitan antara kepentingan yang berdimensi keagamaan dengan kepentingan-kepentingan aktual seperti kepentingan ekonomi dan politik. Kepentingan ekonomi dan politik tersebut seringkali menjadi pemicu konflik dalam masyarakat. Hal ini dapat dilihat dari pengakuan negara terhadap 6 agama resmi dan mempertegas dikotomi antara agama yang "legal" dan yang "illegal", bahkan dapat dikatakan sebagai agama yang "benar" dan yang "sesat".

Negara mulai "dianggap" menghegemoni kebebasan beragama masyarakat melalui dibentuknya badan yang disebut Badan Koordinasi Pengawas Aliran Ke- 
percayaan Masyarakat (Pakem) Kejaksaan Republik Indonesia dan Undang Undang No. 1/PNPS/1965 tentang pencegahan penyalahgunaan agama dan atau penodaan agama. Kemunculan paket kebijakan tersebut tidak dapat dilepaskan dari situasi sosial-politik pascakemerdekaan. Niels Mulder dalam Kholiludin (2009:151) menyatakan bahwa Departemen Agama pada tahun 1953 mencatat bahwa terdapat lebih dari 360 kelompok kebatinan yang terdapat di wilayah Jawa yang memiliki peran dalam kehidupan masyarakat sehingga parta-partai Islam pada Pemilu 1955 gagal memperoleh suara mayoritas (hanya mendapat $42 \%$ suara).

Pada tahun 1952 diadakan sidang Dewan Perwakilan Rakyat yang mengusulkan agar Departemen Agama membuat rumusan definisi agama sehingga saat itu muncul rumusan unsur-unsur esensial agama berupa Nabi/Rasul, kitab suci, dan pengakuan dari luar negeri. Hal tersebut membuat kalangan Hindu-Bali tidak menyetujui rumusan tersebut sehingga definisi agama tidak pernah muncul dalam regulasi. Pada tahun 1953 Departemen Agama melaporkan adanya 360 agama baru di Indonesia sehingga muncul kebijakan yang menempatkan Pakem sebagai salah satu biro di bawah struktur Departemen Agama. Pakem merupakan akronim dari Pengawas Aliran Kepercayaan Masyarakat, meskipun di beberapa daerah muncul pemaknaan berbeda mengenai definisi Pakem. Ada yang memahami sebagai pengawas preventif, ada yang memaknai hanya sebagai Peninjau Aliran Kepercayaan Masyarakat, dan ada yang memaknai sebagai Penelitian dan Pengembangan Aliran Masyarakat (Kholiludin, 2009:153).

Pada tahun 1958 Kejaksaan Agung membentuk Bagian Gerakan Agama dan Kepercayaan Masyarakat dan selanjutnya diresmikan menjadi Biro Pakem pada tahun 1960. Pada tahun 1961 Biro Pakem didirikan di setiap provinsi dan kabupaten melalui Surat Edaran Departemen Kejaksaan Biro Pakem Pusat No. 34/Pakem/S.E./61 tanggal 7 April 1961 dengan tugas mengikuti, memerhatikan, mengawasi, gerak gerik serta perkembangan dari semua gerakan agama, semua aliran kepercayaan/kebatinan, memeriksa/mempelajari buku-buku, brosur keagamaan/aliran kepercayaan, baik yang berasal dari dalam maupun luar negeri. Tugas Pakem disempurnakan dalam Surat Instruksi Jaksa Agung No.1/ Insr/Secr/1963 tanggal 5 Februari 1963 tentang Penyelesaian Persoalan di Bidang Pakem Kejaksaan yang menegaskan pada pengawasan yang diarahkan pada gejala-gejala yang dapat menghalangi jalannya pembangunan (Baso, 2005:242-243).

$$
\text { Konstitusi yang mulai }
$$

mendiskriminasi kepercayaan lokal terdapat pada dibentuknya Undang Undang No. 16 tahun 2004 mengenai tugas pengawasan aliran kepercayaan tercantum pada Bab III Pasal 30 ayat 3 (d). Peraturan serupa juga terdapat dalam Undang Undang No. 5 tahun 1991 dalam Bab III Pasal 27 ayat 3 (d) dan Undang Undang No. 15 tahun 1961 dalam Bab I Pasal 2 ayat 3. Pada tanggal 27 Januari 1965 Penetapan Presiden (PP) No. 1 (selanjutnya ditulis PNPS 1965) dikeluarkan oleh Soekarno tentang Pencegahan Penyalahgunaan dan atau Penodaan Agama. Status PP ini kemudian ditingkatkan sebagai Undang Undang melalui penetapan Undang Undang No. 5 tahun 1969 yang dalam perkembangannya menjadi alat untuk membentengi agama resmi dari aliran-aliran kepercayaan (Kholiludin, 2009:159).

Penegasan dikotomi agama resmi yang diakui negara juga dapat dilihat dalam UUDS 1950 pasal 43 ayat 3 dan UUD RIS pasal 41 ayat 1 dan 2 . Hal tersebut menguatkan bahwa negara memiliki wewenang untuk memberikan pengakuan resmi, memberikan perlindungan, dan bantuan hanya kepada agama resmi (Baso, 2005:239). Dasar legal formal mengenai diskursus agama resmi tersebut dikukuhkan oleh konstitusi negara. Perjalanan panjang "kebijakan" negara tersebut juga berpengaruh pada kehidupan beragama masyarakat Indonesia pada umumnya dan masyarakat Tengger Brang Kidul di Desa Ngadas pada khususnya. Aturan negara cenderung memaksa masyarakat untuk memilih salah satu agama resmi dan hal ini menghasilkan suatu dialektika masyarakat Tengger Brang Kidul di Desa Ngadas dalam kehidupan beragama. Di satu sisi, masyarakat harus takluk dan mematuhi peraturan negara, di sisi lain masyarakat 
masih memiliki keyakinan yang menjadi warisan nenek moyang secara turun temurun.

\section{Gambaran Umum Masyarakat Teng- ger Brang Kidul di Desa Ngadas, Ke- camatan Poncokusumo, Kabupaten Malang, Jawa Timur}

Tengger secara etimologis (Widyaprakosa, 1994:26) memiliki arti berdiri tegak atau diam dan tidak bergerak. Pengertian Tengger jika dikaitkan dengan kepercayaan yang hidup dalam masyarakat dapat diartikan tenggering budi luhur. Tengger juga memiliki arti sebagai tanda atau cirri yang memberikan sifat khusus pada sesuatu. Pengertian Tengger dapat dikatakan sebagai sifat-sifat budi pekerti luhur. Tengger juga memiliki pemaknaaan lain dalam kepercayaan masyarakat pendukungnya. Sebutan Tengger tidak terlepas dari legenda nenek moyang masyarakat Tengger. Legenda Rara Anteng dan Jaka Seger merupakan sejarah yang diyakini masyarakat Tengger sebagai awal mula keberadaan mereka. Rara Anteng dan Jaka Seger adalah sepasang suami-istri yang memiliki 25 anak, namun salah satu diantaranya menjadi tumbal dengan dijerumuskan ke dalam kawah Bromo demi keselamatan keluarganya. Dalam kisah ini, Tengger merupaka akronim dari kata "teng" dari Rara Anteng dan "ger" dari Joko Seger. Anteng memiliki makna kedamaian dan seger memiliki maka kesuburan. Hal tersebut tercermin pula dalam kehidupan masyarakat Tengger yang penuh kedamaian, hidup sederhana, gotong royong, dan toleran.

Tengger Brang Kidul adalah komunitas adat Tengger yang mendiami wilayah Malang atau selatan atau Brang Kidul. Tengger Brang Kulon untuk wilayah $\mathrm{Pa}$ suruan, Tengger Brang Lor untuk wilayah Probolinggo, dan Tengger Brang Wetan untuk menyebut masyarakat yang tinggal di wilayah Lumajang. Berbeda dengan daerah Tengger lain yang menempati wilayah Malang, Desa Ngadas merupakan satu-satunya desa yang masih mempertahankan identitas ketenggeran mereka, sehingga masyarakat Tengger di daerah lain (selain Brang Kidul) masih menyebut mereka dengan sebutan wong Tengger Brang Kidul.

Jawa Sanyata merupakan kepercayaan yang hanya dimiliki oleh mas- yarakat Tengger Brang Kidul di Desa Ngadas. Jawa Sanyata merupakan sebuah ajaran yang dibawa oleh $\mathrm{Ki}$ Kere atau $\mathrm{Ki}$ Sabda Gedibal yang menurut cerita masyarakat berasal dari Jogonalan, Klaten. Ia datang ke Desa Ngadas sekitar tahun 1970an dan meninggalkan kitab yang menjadi tuntunan bagi penganut Jawa Sanyata yaitu Kitab Adam Makna. Sebagian besar masyarakat Tengger Brang Kidul di desa setempat merupakan satu-satunya masyarakat yang meyakini Hyang Wenanging Jagat sebagai sebutan khas untuk Tuhan Yang Maha Esa. Ki Kere atau Ki Sabda Gedibal sendiri dianggap sebagai pembawa wahyu, ia juga dianggap sebagai sosok yang misterius karena ia datang secara tiba-tiba dan menghilang secara tiba-tiba, sebagian masyarakat meyakini bahwa ia sudah moksa.

Dalam konteks geografis, bentang fisik kawasan Tengger ada seluas kurang-lebih $40 \mathrm{~km}$ dari utara ke selatan, $20-30 \mathrm{~km}$. Wilayah Tengger terletak pada bagian dari 4 kabupaten: Probolinggo, Pasuruan, Malang, dan Lumajang. Tipe permukaan tanahnya bergunung-gunung dengan tebing yang curam. Kaldera Tengger merupakan lautan pasir terluas yang terletak pada ketinggian $2300 \mathrm{~m}$ dengan panjang 5-10 km. Data di Puslit Universitas Jember menunjukkan bahwa kawah Gunung Bromo dengan ketinggian 2.392 $\mathrm{m}$ masih aktif mengeluarkan asap yang menggelombang ke angkasa Sedang di sebelah selatan menjulang puncak Gunung Semeru dengan ketinggian 3.676 m (Adrianto, 2002:21).

Penelitian ini dilakukan di Desa Ngadas, Kecamatan Poncokusumo, Kabupaten Malang, Jawa Timur. Desa Ngadas merupakan desa yang berada di area Taman Nasional Bromo Tengger Semeru yang memiliki akses terdekat dengan Gunung Bromo bila ditempuh dari kota Malang. Jarak yang ditempuh dari ibu kota Malang menuju Desa Ngadas adalah 48 $\mathrm{km}$ atau selama 2 jam, sedangkan jarak yang ditempuh dari Kota Surabaya adalah $118 \mathrm{~km}$ atau selama 5 jam dengan kendaraan bermotor. Desa Ngadas berbatasan dengan Desa Mororejo, Kecamatan Tosari, Kabupaten Pasuruan di sebelah utara. Desa Ngadas berbatasan pula dengan Desa Ranupani, Kecamatan Senduro, Kabupaten Lumajang di sebelah selatan. Desa Ngadas 
berbatasan dengan Desa Ngadisari, Kecamatan Sukapura, Kabupaten Probolinggo di sebelah timur dan Desa Gubugklakah di Kecamatan Poncokusumo, Kabupaten Malang.

Luas wilayah pemukiman di Desa Ngadas adalah 14 ha dan luas wilayah tegalan adalah 181 ha dengan luas hutan lindung adalah sekitar 7.000 ha. Desa Ngadas memiliki curah hujan sekitar 3.000-3.500 $\mathrm{Mm}$ dengan tinggi permukaan $2.100 \mathrm{mdl}$ dan suhu rata-rata harian $17-22^{\circ} \mathrm{C}$. Desa Ngadas memiliki topografi wilayah yang berbukit dengan tingkat kemiringan tanah sekitar 20-75 . Masyarakat pada umumnya memiliki lahan pertanian yang ditanami tanaman kentang atau Solanum tuberosum dan kubis atau Brassica oleraceae. Status kepemilikan lahan pertanian sebagai milik pribadi adalah 400 keluarga dan 36 keluarga tidak memiliki kepemilikan lahan pertanian. Masyarakat juga melakukan ternak, yakni 100 orang beternak sapi, 80 orang beternak babi, 30 orang beternak ayam kampung, 5 orang beternak kuda, dan 35 orang beternak kambing.

Dialektika Kehidupan Beragama Mas-
yarakat Tengger Brang Kidul di Desa
Ngadas, Kecamatan Poncokusumo, Ka-
bupaten Malang, Jawa Timur
Data Potensi Desa menyebutkan bahwa jumlah penduduk di Desa Ngadas sampai dengan akhir tahun 2013 sebesar 1.905 jiwa (sekitar $480 \mathrm{KK}$ ) terdiri dari 905 laki-laki dan 955 perempuan. Mayoritas masyarakat Desa Ngadas memeluk agama Buddha dengan aliran Buddha Jawa Sanyata sebanyak 906 orang, agama Islam sebanyak 817 orang, agama Hindu dipeluk oleh 109 orang, dan agama Kristen adalah agama minoritas dengan jumlah pemeluk 4 orang (Potensi Desa Ngadas Tahun 2014). Desa Ngadas di Kecamatan Poncokusumo, Kabupaten Malang, Jawa Timur memiliki beberapa sarana peribadatan sesuai agama yang dipeluk masyarakat, yakni masjid, mushola, vihara, dan pura. Sebuah masjid, sebuah pura, dan 2 buah mushola berada di wilayah pemukiman warga, sedangkan sebuah vihara berada di dekat area pemakaman dan pedahnyangan yang dikeramatkan masyarakat. Namun demikian, Desa Ngadas belum memiliki fasilitas gereja bagi pemeluk agama Kristen.

Agama Buddha menjadi agama re- smi yang diakui oleh mayoritas masyarakat Tengger Brang Kidul di Desa Ngadas karena masyarakat meyakini bahwa agama Buddha merupakan agama resmi negara yang relevan dengan keyakinan ke-Buda-an mereka. Dominasi aliran Maitreya kemudian muncul ketika para pemeluk Maitreya dari Kota Malang memberikan "perhatian". Masyarakat setempat meyakini bahwa Maitreya merupakan aliran yang mengutamakan ajaran cinta kasih sehingga dianggap memiliki kesamaan dengan esensi ajaran Jawa Sanyata yang mereka yakini sejak dulu.

Buddha Jawa Sanyata lahir dan berawal dari kemelut politik pada masa orde baru. Pemberontakan PKI yang terjadi pada tahun 1965 menggerakkan pemerintah untuk memerangi dan menumpas habis gerakan komunis tersebut. Setelah pergolakan tersebut pemerintah membuat kebijakan dengan mewajibkan setiap warga negara untuk memeluk salah satu agama resmi Negara (Islam, Katolik, Hindu, Buddha, Kristen Protestan). Pemerintah juga menghadirkan stigma komunis dan atheis bagi setiap warga negara yang tidak mau memeluk salah satu agama resmi tersebut. Stigma tersebut juga menghantui masyarakat Tengger yang membuat mereka was-was karena keyakinan mereka berbeda dengan agama yang diakui oleh pemerintah saat itu (Hefner, 1985:243).

Kondisi tersebut mengakibatkan para tokoh dan Dukun Pandhita ${ }^{1}$ se-Tengger mengadakan pasamuan pada tahun 1973 yang menentukan agama resmi yang hendak dipilih dan dirasa sesuai oleh masyarakat setempat. Pada saat itu para peserta pasamuan sepakat untuk memilih Hindu sebagai agama resmi, kecuali Mbah Ngatrulin. Mbah Ngatrulin adalah seorang dukun yang berasal dari Desa Ngadas dan merupakan sesepuh yang dianggap memiliki pengetahuan yang mendalam mengenai sejarah dan kehidupan masyarakat Desa Ngadas. Ia menolak keputusan tersebut dan bersikukuh ingin tetap mempertahankan agama Buda (Jawa Sanyata). Akhirnya masyarakat Desa Ngadas yang menganggap keyakinan mereka dengan

1 Dukun yang dimaksud adalah sebutan bagi orang yang memimpin ritual adat, memiliki pengetahuan tentang masyarakat dan kearifan lokal setempat, serta dianggap sebagai orang terhormat atau sesepuh 
sebutan Buda yang sudah terbalut ajaran Jawa Sanyata memutuskan untuk ikut ke dalam agama Buddha dengan alasan bahwa ajaran Buda atau Jawa Sanyata sebenarnya lebih mengarah ke ajaran agama Buddha daripada ajaran Hindu. Persamaan tersebut terdapat pada ajaran welas asih (kasih sayang) yang menjadi pedoman kehidupan bermasyarakat dan beragama mereka. Dalam sistem keyakinan mereka saat itu, mereka juga mengenal sosok Sri Maharaja Dewa Buda ${ }^{2}$. Selain karena mereka memutuskan untuk masuk ke dalam agama Buddha, kata Buda juga identik dengan Buddha, dari hal tersebut kemudian muncul istilah Buddha Jawa Sanyata.

Pada awal mereka memutuskan untuk memeluk agama Buddha Jawa Sanyata, mereka mejalankan praktik upacara keagamaan yang berbeda dengan umat Buddha pada umumnya. Mereka menjalankan praktik upacara keagamaan sesuai dengan tradisi leluhur dan seperti yang diajarkan dalam Kitab Adam Makna. Mereka melaksanakan upacara keagamaan di tempat yang disebut dengan Sanggar Pasembahan Jawa Sanyata. Pada awalnya mereka juga sama sekali tidak mengenal beberapa pusat orientasi dalam agama Buddha seperti Sidharta Gautama dan Kitab Tripitaka maupun jenis upacara keagamaan dalam agama Buddha seperti Waisak.

Namun hal tersebut berubah seiring berjalannya waktu dengan masuknya ajaran Buddha Dharma ke Desa Ngadas sejak tahun 1992. Mulai saat itu gencar dilakukan berbagai macam sosialisasi dan pembinaan kepada warga penganut Buddha Jawa Sanyata. Secara keorganisasian Walubi masuk ke desa Ngadas pada tahun 1995. Pada tahun 1992 mulai dibagun sebuah tempat peribadatan Vihara yang sebelumnya merupakan bangunan Sanggar

2 Kurang jelas apakah yang dimaksud adalah Sidharta Gautama atau bukan. Masyarakat setempat mengenalnya sebagai salah satu pembawa wahyu dari Tuhan. Nama Sri Maharaja Dewa Buda disebutkan dalam naskah Serat Pustaka Raja Purwa atau Serat Paramayoga karangan Ranggawarsita (Darmasubita, 1928). Dalam Serat tersebut Ia disebutkan merupakan penjelmaan dari Batara Guru, merupakan raja pertama dari kerajaan Medang Kamulan yang merupakan kerajaan pertama di tanah Jawa. Ia yang mengajarkan kawruh atau ilmu welas asih (kasih sayang) dan tata cara menyembah Tuhan.
Pasembahan yang bentuknya terlihat lebih sederhana. Vihara yang terletak di Desa Ngadas disebut Vihara Paramita yang terletak di dekat Pedahnyangan tidak jauh dari pemakaman desa. Vihara dibangun dengan menggunakan dana swadaya umat Buddha di Desa Ngadas. Mulai saat itu gencar dilakukan berbagai macam sosialisasi dan pembinaan kepada warga penganut Buddha Jawa Sanyata. Perubahan tersebut salah satunya tidak lepas dari peran Pak Ngatono, seorang pemeluk keyakinan Jawa Sanyata dari desa Ngadas yang menjadi agen of change. Beliau pernah belajar ajaran Buddha Dharma di Malang pada tahun 1992 hingga tahun 1995. Pak Ngatono pun mulai memperkenalkan ajaran Buddha Dharma dan Sidharta Gautama kepada masyarakat Ngadas pemeluk Jawa Sanyata. Pada saat itu ajaran Buddha Dharma kurang mendapat perhatian dari masyarakat pengikut Jawa Sanyata. Akhirnya seiring berjalannya waktu ajaran tersebut dapat diterima dengan baik oleh masyarakat karena secara esensi kedua ajaran tersebut pada dasarnya sama. Hal tersebut memunculkan bentuk akulturasi seperti dalam ajaran dan dogma serta dalam beberapa praktik upacara keagamaan. Masyarakat kemudian juga mulai merayakan perayaan Buddha Dharma seperti Waisak yang mereka lakukan sejak tahun 1998 atas bimbingan Walubi. Saat itu perayaan upacara Waisak digelar bersama dengan majelis dalam agama Buddha lainnya di lingkungan Malang dan sekitarnya yang bertempat di Candi Sumberawan yang terletak di Kecamatan Singosari Malang. Pada saat ini mereka juga merayakan upacara Waisak di Sanggar Pasembahan yang juga dihadiri oleh beberapa anggota majelis agama Buddha di lingkungan Malang.

Pada tahun 2002 juga masuk salah satu aliran dalam agama Buddha, yaitu Maitreya yang turut membentuk wajah baru dalam ajaran, praktik upacara keagamaan dan di beberapa sudut bangunan ibadah. Masyarakat penganut Jawa Sanyata tidak serta merta menerima ajaran yang berasal dari luar, mereka juga melakukan filterisasi terhadap ajaran yang masuk. Ajaran Maitreya dapat diterima dengan alasan bahwa ajaran tersebut pada dasarnya berlandaskan pada welas asih atau kasih sayang. Maitreya merupakan aliran yang diakui oleh kelembagaan Walubi. Maitreya 
saat ini sesungguhnya adalah Bodhisattva (calon Buddha) yang akan datang ke bumi pada saat kiamat akan tiba untuk menyelamatkan umat manusia dengan ajaran kisah kasih. Maitreya dalam tiap figurnya digambarkan sebagai sosok yang membawa kedamaian dan kebahagiaan karena selalu digambarkan tersenyum (Sponberg dan Hardacre, 1988:2-3). Masyarakat penganut Jawa Sanyata tidak serta merta menerima ajaran yang berasal dari luar. Mereka juga melakukan filterisasi terhadap ajaran yang masuk. Ajaran Maitreya dapat diterima dengan alasan bahwa ajaran tersebut pada dasarnya berlandaskan pada welas asih atau kasih saying.

Kehidupan beragama mereka semakin lengkap dengan adanya bangunan monumental sebagai tempat peribadatan yaitu Vihara Paramitta yang dibangun pada tahun 2005. Bangunan tersebut dibangun pada lahan milik desa dan merupakan bekas tempat bangunan sebelumnya yaitu Sanggar Pasembahan yang mempunyai ukuran lebih kecil. Tempat ibadah yang terdiri dari satu bangunan tersebut mempunyai dua nama yang berbeda, di satu sisi bernama Vihara Paramitta dan di sisi lain bernama Sanggar Pasembahan Jawa Sanyata yang ditulis menggunakan huruf Jawa.

Satu bangunan dua nama adalah bangunan yang saat ini digunakan oleh umat Buddha Jawa Sanyata sebagai tempat untuk menjalankan praktik upacara keagamaan. Pada sisi depan bangunan nama yang menonjol adalah Vihara Paramitta, sedangkan pada sisi samping tertulis nama Sanggar Pasembahan Jawa Sanyata yang ditulis menggunakan huruf Jawa dalam sebuah papan kayu. Di kalangan masyarakat bangunan tersebut lebih popular dengan sebutan sanggar ataupun Vihara. Bangunan yang dibangun di atas tanah milik desa tersebut berbentuk bujur sangkar, memperlihatkan kaidah konsep jawa yaitu papat kiblat, yang juga terlihat dari bentuk atap bangunan yang pada masing-masing sisi menghadap ke empat arah. Bangunan sanggar pasembahan atau Vihara pada awalnya lebih kecil daripada sekarang yang di dalamnya hanya berisi altar persembahan kepada Hyang Wenang ing Jagad. Pada tahun 2005 bangunan tersebut dipugar dan menjadi bangunan yang mempunyai ciri yang sedikit berbeda dengan bangunan sebelumnya. Setelah pembangunan kembali bangunan peribadatan tersebut yang mendapat sokongan dari Maitreya terdapat tampilan yang sedkit berbeda di dalamnya. Di altar persembahan terdapat patung Maitreya dengan background di belakangnya sebuah gambar Sang Buddha. Pada saat ini terlihat di dalam bangunan pada bagian altar pasembahan terdapat 3 patung berbeda yang merepresentasikan identitas masing-masing ajaran yang ada di kalangan masyarakat penganut Jawa Sanyata. Yang pertama adalah patung Ismaya dengan background yang terdapat di sisi kiri altar, yang merepresentasikan ajaran Jawa Sanyata, kemudian patung Sang Buddha dengan background Gunung Semeru yang berada di sisi tengah altar yang merepresentasikan ajaran Dharma, dan patung Maitreya dengan background stupa yang berada di sisi kanan altar yang merepresentasikan ajaran Maitreya. Pada sisi altar lainnya yaitu perlengkapan yang digunakan sebagai sarana ibadah juga tampak percampuran ketiga identitas yang berbeda tersebut. Di meja altar persembahan yang tiap sudutnya dihiasi janur kuning digunakan beberapa perlengkapan peribadatan seperti bokor dan dupa serta perabotan seperti guci cina dan kipas yang terdapat tulisan cina. Di samping itu juga terdapat persembahan dalam sebuah wadah persembahan. Pada sisi dinding juga dihiasi dengan beberapa hiasan seperti gambar Semar yang disusun dari sekumpulan huruf Jawa, foto dari $\mathrm{Ki}$ Kere atau Ki Sabda Gedibal, dan gambar Sang Buddha.

Keberadaan 3 patung yang diyakini masyarakat Desa Ngadas sebagai pusat orientasi memperlihatkan terjadinya kompromi dan negosiasi masyarakat yang tetap mempertahankan ideologi Jawa Sanyata sehingga tetap menggunakan figur Ismaya sebagai pratima di altar. Buddha sebagai pusat orientasi agama Buddha Dharma yang diakui pemerintah juga menjadi pratima yang diposisikan di sentral altar dengan ukuran yang lebih besar. Figur Maitreya juga diterima masyarakat sebagai Buddha cinta kasih yang dianggap merepresentasikan jiwa cinta kasih yang dimiliki masyarakat Tengger Brang Kidul di Desa Ngadas dengan meletakkan pratima Maitreya di altar. Hal tersebut menunjukkan terjadinya pemakaian simbolik unsur-unsur budaya asing berupa ideologi baru bagi 
penegasan keberadaan umat Buddha di Desa Ngadas.

Setiap hari Rabu terdapat kegiatan yang disebut dengan Sekolah Minggu, dimana kegiatan transformasi pengetahuan dari orang tua kepada anak-anak dilakukan. Di dalam kegiatan tersebut diajarkan tentang Jawa Sanyata seperti ajaran tata cara beribadah. Selain itu juga diajarkan bagaimana menulis huruf Jawa dan bernyanyi menggunakan tembang macapat. Ajaran dharma juga diajarkan terutama berkaitan dengan Siddharta Gautama serta sejarah perkembangan agama Buddha sendiri. Tak juga ketinggalan ajaran Maitreya juga ikut andil dalam kegiatan tersebut terutama berkaitan dengan ajaran kasih sayang. Selain itu anak-anak juga diajarkan lagu-lagu Maitreya yang kerap digunakan dalam ibadah liturgi.

Terdapat usaha-usaha untuk memasukkan ajaran Maitreya ke dalam sistem keyakinan mereka. Sasaran utama mereka adalah generasi muda yang menjadi pewaris ajaran dan adat mereka. Dahulu banyak anak muda yang dikirim ke Surabaya untuk mengikuti pelatihan-pelatihan dan mengikuti pembelajaran ajaran Maitreya. Pemerintah juga melakukan pendisiplinan terhadap ajaran Buddha Jawa Sanyata yang dilakukan terhadap anak-anak yang menempuh pendidikan formal. Anak-anak Desa Ngadas yang kebanyakan menempuh pendidikan dasar di SD Ngadas 1 tidak mendapatkan pelajaran Jawa Sanyata, tetapi mereka mendapatkan pelajaran Agama Buddha Dharma.

Permasalahan yang dihadapi masyarakat Buddha Jawa Sanyata di Desa Ngadas saat ini (hingga tulisan ini dibuat) adalah berkaitan dengan Vihara. Hak milik tanah atas Vihara tersebut adalah milik Desa sehingga masyarakat harus mencari alternatif tempat untuk membangun Vihara mereka yang baru di bawah kepemilikan Lembaga Keagamaan Buddha Indonesia di Desa Ngadas mengingat tempat ibadah agama lain sudah merupakan hak milik organisasi keagamaan mereka masing-masing untuk menghindari sengketa. Motivasi dan usaha yang dilakukan masyarakat Desa Ngadas dalam mempertahankan kepercayaan mereka mempertegas bahwa masyarakat setempat merupakan subjek yang menjadi agen pemertahan ideologi lokal yang merupakan tradisi turun tem- urun sebagai warisan nenek moyang. Mereka bertarung dalam sebuah arena yang di dalamnya terdapat kekuatan-kekuatan dan dominasi dari para agen yang membawa ideologi baru. Adaptasi dan negosiasi dilakukan agar masyarakat tetap dapat mempertahankan dan memperjuangkan ideologi asli mereka.

Masyarakat setempat mengidentifikasi keyakinan mereka sebagai Buda sejak sebelum terjadi pergolakan 1965. Setelah pergolakan 1965 tangan-tangan pemerintah sempat mengeluarkan beberapa kebijakan sehubungan dengan bentuk keyakinan dari masyarakat Tengger. Pada tahun 1968 pemerintah melalui Depertemen Kehakiman menetapkan status "Kepercayaan terhadap Tuhan Yang Maha Esa" kepada segala macam bentuk praktik upacara keagamaan masyarakat Tengger. Pada saat itu masyarakat Tengger merasa tidak puas dengan kebijakan tersebut karena keyakinan mereka tidak diakui sebagai agama resmi. Hal tersebut dikemukakan oleh Bapak Sutomo:

"kalo ga ada tuntutan politis ya,, dari pemerintah, mungkin ya tetep Siwa Buddha, Siwa Buddha terakhir adalah Majapahit, kan.. kami ini adalah penerus Siwa Buddha itu.. karena sudah menjadi keputusan pemerintah semua yang ada di NKRI ini harus jelas status keagamaannya, dan yang direstui pemerintah tidak ada agama Siwa Buddha, waktu itu hanya 5 agama, hanya itu." (Wawancara 29 Agustus 2014)

Setelah kebijakan tersebut keluar, tangan-tangan Buddha maupun Hindu mulai menyusup ke dalam kehidupan masyarakat Tengger. Pada tahun 1968 banyak orang yang dimasukkan sebagai umat agama Buddha dan mengangkat beberapa Dukun Pandhita menjadi seorang Biksu. Pada tahun 1969 Hindu juga membuat counter attack dengan memasukkan beberapa masyarakat Tengger sebagai umat agama Hindhu. Mereka juga mengangkat Dukun Pandhita menjadi seorang Pemangku sehingga pada tahun 1973 pemerintah membuat kebijakan baru terkait bentuk keyakinan masyarakat Tengger melalui Parisadha Hindu Dharma Indonesia (PHDI) Provinsi Jawa Timur. Pada saat itu digelar pertemuan antara Dukun Pandita seluruh wilayah 
adat tengger yang meliputi empat kabupaten (Malang, Probolinggo, Pasuruan, Lumajang) untuk menentukan keyakinan mereka. Pertemuan tersebut digelar tahun 1973 yang bertempat di Balai Desa Ngadisari, sebuah wilayah adat Tengger yang berada di Kabupaten Probolinggo. Pertemuan tersebut digelar sebagai imbas dari kebijakan pemerintah yang mengharuskan untuk memeluk salah satu agama resmi dan menghindarkan masyarakat dari stigma ateis dan komunis, serta imbas dari kebijakan pemerintah yang membuat masyarakat bingung mengidentifikasi keyakinan mereka sendiri. Selanjutnya pemerintah mengkategorikan masyarakat Tengger sebagai pemeluk Buddha Mahayana. Keputusan tersebut tertuang dalam Surat Keputusan No. 00/PHB Jatim/Kept/III/1973 tanggal 6 Maret 1973.

Pada saat itu antara Buddha dan Buda Tengger seperti yang ditunjukkan oleh hasil penelitian Ayu Sutarto (1997) persamaannya hanya terdapat pada kata Hong yang biasa digunakan oleh Dukun Pandhita Tengger sebagai awalan dalam pembacaan doa dan mantra yang identik dengan kata Hong dalam agama Buddha. Meskipun demikian dalam hal orientasi keagamaan maupun dalam praktik upacara keagamaan keduanya sangat berbeda. Tak lama kemudian masih di tahun 1973, pemerintah kembali membuat kebijakan baru dengan menetapkan keyakinan masyarakat Tengger sebagai varian dari agama Hindu. Hal tersebut didasarkan pada alasan bahwa upacara adat Tengger banyak yang bersumber dari kitab Weda dan kesamaan sebagian Dewa yang dipuja oleh masyarakat Tengger dengan Dewa dalam agama Hindu. Kebijakan yang berubah dalam waktu yang tidak lama tersebut sebenarnya membuat masyarakat Tengger sendiri bingung untuk mengidentifikasi keyakinan mereka. Sebagian masyarakat Tengger merasa bahwa kebijakan terakhir tersebut membuat seolah masyarakat Tengger telah dihindukan oleh pemerintah. Akibatnya istilah Buda yang sebelumnya melekat sebagai identitas keyakinan masyarakat Tengger dengan perlahan tergeser oleh istilah Hindu Tengger. Eksistensi Buda yang saat itu menjadi keyakinan masyarakat Tengger sebenarnya juga berbeda dengan bentuk praktik upacara keagamaan agama Buddha maupun agama Hindu yang diakui pemerintah saat itu. Banyak yang mengintepresentasikan bahwa Tengger adalah Hindu atau Buddha maupun Hindu-Buddha karena leluhur mereka adalah pelarian dari Majapahit. Namun hal tersebut terbantahkan dengan fakta bahwa di Tengger tidak ada tempat ibadah yang bernama Pura maupun Vihara maupun adanya Pemangku maupun Bhiksu. Tempat peribadatan mereka disebut dengan Sanggar Pamujan, sedangkan pemimpin upacara adat maupun keagamaan adalah Dukun Pandhita. Kenapa demikian? Pada masa kerajaan Majapahit berbagai literatur mengatakan bahwa agama yang dianut oleh Majapahit adalah Siwa-Buddha. Perpaduan kedua ajaran yaitu Siwa-Buddha tersebut kemudian dikenal dengan istilah Buda. Saat banyak pelarian dari Majapahit melarikan diri ke kawasan Tengger terdapat kemungkinan mereka membawa ajaran tersebut serta adat yang kemudian berpadu dengan kepercayaan lokal masyarakat setempat. Pada masa kerajaan Majapahit kedua agama tersebut dapat hidup berdampingan sehingga tidak ada kompetisi antara keduanya. Bahkan dalam Kitab Sutasoma disebutkan "Siwa-Buddha bhinneka tunggal ika tan hana dharmma mangrwa", hal tersebut menyiratkan bahwa pada hakekatnya kedua ajaran tersebut sama. Bentuk ajaran Siwa-Buddha tersebut kemudian mengalami sinkretisme dengan kepercayaan lokal masyarakat setempat sehingga memunculkan bentuk keyakinan baru. Bentuk keyakinan baru tersebut nampak dari unsur-unsur religi masyarakat Tengger yang masih terdapat unsur Siwa maupun Buddha serta bentuk kepercayaan lokal yang tidak terdapat di dalam kedua ajaran tersebut. Hal tersebut sejalan dengan teori yang diungkapkan oleh Rassers (1992) bahwa sinkretisme Siwa-Buddha terjadi karena adanya pengaruh kebudayaan asli Jawa, serta pendapat Suamba (2007) yang melukiskan pertemuan Siwaisme dan Buddhisme sebagai percampuran melalui adopsi dan kemudian terjadi penataan kembali sesuai dengan alam pikiran kebudayaan Jawa. Hal tersebut berarti bahwa peran paling penting dalam proses mempertemukan kedua ajaran dan penataan kembali ajaran tersebut terdapat dalam peran kearifan lokal masyarakat Jawa. Hal yang berbeda terjadi pada masa kolonial dimana ajaran Siwa yang dominan secara 
dogmatis berdiri menjadi agama Hindhu secara teologis, sedangkan ajaran Buddha yang dominan secara dogmatis berdiri menjadi agama Buddha secara teologis meskipun di dalam kedua agama tersebut terdapat sekte yang berbeda-beda.

Terdapat kemungkinan dahulu di Tengger terdapat penganut dari ajaran Siwa maupun penganut dari ajaran Buddha. Ajaran Siwa yang telah terbalut kepercayaan lokal kemudian diidentifikasi sebagai Hindu Tengger, sedangkan ajaran Buddha yang telah terbalut kepercayaan lokal diidentifikasi sebagai Buddha Tengger yang kemudian lebih popular dengan istilah Buda. Keadaan tersebut berubah pada masa kolonial bahwa Hindu dan Buddha adalah agama yang terpisah dan berdiri sendiri.

Masyarakat Hindu di Desa Ngadas berada di bawah naungan Parisadha Hindu Dharma Indonesia (PHDI) Desa Ngadas. Kepengurusan PHDI Desa Ngadas didirikan pada tahun 1986, bersamaan dengan pembangunan Pura Sapto Argo. Ketua PHDI Desa Ngadas untuk pertama kali dipimpin oleh Mbah Kadar. Pura tersebut didirikan di tanah milik Mbah Kadar yang kemudian disumbangkan pada umat karena Beliau tidak memiliki keturunan. Masyarakat Hindu di Desa Ngadas tetap melakukan ritual adat ke-Tengger-an. Mereka juga meyakini dan mengenal ajaran agama Hindu resmi dari pemerintah. Mereka meyakini Sang Hyang Widhi sebagai pencipta dan kitab suci Weda. Layaknya umat Hindu di Bali, umat Hindu di Desa Ngadas juga merayakan hari suci seperti Galungan, Kuningan, Nyepi, Pagerwesi, Siwaratri, dan Saraswati. Umat Hindu setempat juga melakukan ritual piodalan di Pura setempat. Ritual keagamaan khas Hindu dilaksanakan dengan menggunakan upakara sesuai tradisi Bali yang menggunakan material berupa janur (daun kelapa), kelapa, dan sebagainya. Bahkan pelaksanaan melasti pun yang pada awalnya diselenggarakan di sumber air Tengger di Widodaren, kini masyarakat lebih memilih untuk melakukan ritual tersebut di Bale Kambang yang lokasinya berada jauh dari Desa Ngadas.

Perkembangan agama Islam di Desa Ngadas juga ditunjang melalui perkawinan masyarakat setempat dengan para pendatang. Di Desa Ngadas dahulu ban- yak pendatang laki-laki yang beragama Islam yang kemudian menikah dengan gadis setempat. Kebanyakan dari gadis-gads yang diperistri pendatang yang beragama Islam tersebut mengikuti agama dari suami. Masyarakat setempat juga penasaran dengan cara yang diajarkan secara damai oleh masyarakat lainnya sehingga membuatnya tertarik untuk masuk agama Islam. Pengalaman tersebut juga dialami oleh Mujianto yang masuk Islam karena tertarik dengan agama tersebut. Pada saat menempuh pendidikan di SMP ia banyak mendapatkan pelajaran agama Islam padahal agamanya saat itu adalah Hindhu. Setelah cukup lama kemudian ia meminta ijin kepada orang tuanya untuk pindah, keinginannya tersebut kemudian diamini oleh orang tuanya. Pada tahun 1990an saat agama Islam mengalami perkembangan di Desa Ngadas, masyarakat penganut agama Islam belum memiliki tempat peribadatan sehingga peribadatan banyak dilakukan di rumah. Pada saat itu penggunaan atribut seperti pakaian muslim untuk perempuan dan jilbab masih sangat terbatas. Para perempuan masih memakai pakaian yang biasa dipakai masyarakat lainnya seperti penggunaan kethu dan kain sarung. $\mathrm{Pa}-$ kaian muslimah dan jilbab pada saat ini dipakai sebagai wujud identitas keislaman perempuan Desa Ngadas dan juga berfungsi untuk memberi kehangatan pada tubuh. Hal tersebut dikarenakan mereka hidup di daerah yang dingin, terutama pakaian muslimah sebenarnya lebih banyak menutupi bagian tubuh.

Perkembangan Islam di Desa Ngadas semakin pesat seiring dibangunannya bangunan peribadatan meskipun masih berwujud Langgar atau Mushala. Bangunan tersebut adalah Mushala Hidayatullah yang dibangun pada tahun 1996. Mushala tersebut dibangun di atas tanah wakaf dari seorang warga beragama Islam bernama Sutikah. Pada tahun 2000 mulai dibangun bangunan masjid yang selesai dikerjakan dan diresmikan pada tahun 2001. Masjid tersebut adalah masjid Al-Asfiya yang tanahnya merupakan sumbangan dari majelis taklim dan dakwah yang berada di Desa Gubukklakah yaitu desa yang berada di bawah Desa Ngadas. Kehadiran kedua tempat ibadah tersebut semakin memperkokoh eksistensi dan hegemoni Islam di Desa Ngadas. 
Masyarakat Desa Ngadas yang beragama muslim selain melaksanakan upacara yang bersifat adat juga melaksanakan upacara keagamaan mereka seperti contoh Idhul Fitri, Idhul Adha, dan Puasa Ramadhan. Pada bulan Ramadhan sebagian besar masyarakat melaksanakan ibadah puasa sebagai wujud ketaatan mereka dalam beragama. Meskipun demikian terdapat juga warga masyarakat yang melaksanakan ibadah puasa pada hari pertama atau hari pertama dan pada hari terakhir sebagai syarat keabsahan mereka menjalankan ibadah puasa. Hal tersebut dilatarbelakangi oleh pekerjaan mereka yang sebagian besar bertani di ladang yang merupakan sumber perekonomian utama mereka. Setiap pagi mereka harus bekerja di ladang, medan yang jauh dan berat harus mereka lalui sehingga membutuhkan energi yang banyak. Sebelum melaksanakan puasa biasanya masyarakat melakukan selamatan megengan. Megengan sebenarnya merupakan kebiasan adat istiadat masyarakat setempat sebelum melakukan ritual megeng yang digelar pada bulan Kapitu. Namun masyarakat yang beragama Islam juga mengadopsi tradisi tersebut. Tradisi megengan yang dilakukan masyarakat Islam sebelum puasa Ramadhan dilakukan dengan membagikan makanan ke beberapa tetangga di sekitar rumah. Selain tradisi megengan terdapat juga tradisi selamatan dan syukuran kupatan. Tradisi kupatan tersebut dilakukan setelah masyarakat menjalankah ibadah puasa pada bulan Ramadhan yaitu pada hari terakhir saat lebaran. Saat lebaran masyarakat saling berkunjung ke rumah, hal tersebut juga dilakukan oleh beberapa masyarakat lainnya yang bukan beragama Islam. Kupatan adalah menikmati makanan sayur-sayuran yang dilengkapi dengan kupat. Kupat dibuat dari daun janur kuning yang dirajut sedemikan rupa kemudian di dalamnya diisi dengan beras. Kupat tersebut kemudian dimasak dengan menggunakan uap air dari air yang dimasak di bawahnya.

Masyarakat Islam di Desa Ngadas juga melaksanakan upacara yang sifatnya adat, tetapi juga yang bernafaskan Islam seperti tasyakuran saat kelahiran bayi. Pada saat tersebut biasanya mereka akan menyembelih kambing sebanyak 1 buah jika anaknya perempuan dan 2 buah jika anaknya laki-laki. Mereka juga akan menyunatkan anaknya mereka seperti umat Islam pada umumnya, tetapi mereka juga melaksanakan sunatan secara adat yang disebut tetesan mrajakani. Saat akad nikah yang digelar di masjid, setelah prosesi tersebut mereka juga akan melaksanakan upacara perkawinan secara adat yang disebut walagara. Meskipun mereka beragama Islam namun mereka tetap melaksanakan upacara yang sifatnya adat sebagai bentuk penghormatan mereka terhadap adat dan para leluhur. Hal yang unik adalah saat mereka juga mengikuti upacara Kasada sebagai bentuk wujud identitas mereka sebagai wong tengger. Umat muslim Ngadas semakin unik karena melaksanakan upacara yang sebenarnya tidak ada dalam adat kebiasaan masyarakat Ngadas maupun dalam agama Islam. Upacara tersebut pada umumnya dilaksanakan masyarakat jawa yang tinggal di dataran rendah. Upacara yang dilaksanakan tersebut berkaitan dengan upacara kematian seperti telungdinan (tiga hari) yang dilaksanakan tiga hari setelah orang meninggal, pitungdinan (tujuh hari) yang dilaksanakan tujuh hari setelah orang meninggal, patangpuluhan (empat puluh hari) yang dilaksanakan emapt puluh hari setelah orang meninggal, nyatus (seratus hari) yang dilaksanakan seratus hari setelah orang meninggal, dan lain sebaginya.

Kompleksitas masyarakat Muslim di Desa Ngadas dapat dilihat dari berkembangnya aliran Wahabi di desa yang sedikit penduduk, tidak memiliki akses dan fasilitas infrastruktur desa yang memadai, dan masih menjunjung tinggi adat istiadat. Dari cerita Pak Ponadi, komunitas tersebut berawal dari anggota masyarakat yang bernama Sutomo. Setelah orang tersebut menuaikan ibadah haji di Mekkah, dia kemudian tidak mengikuti atau melaksanakan upacara yang bersifat adat.

Kondisi yang berbanding terbalik terjadi pada saat ini dimana masyarakat diperbolehkan untuk memeluk semua agama resmi. Masyarakat yang dahulu kurang permisif terhadap Islam lambat laun begitu toleran terhadap agama tersebut. Sikap toleran tersebut dilandasi karena kesadaran masyarakat terhadap kebebasan untuk memeluk agama, selain itu karena ajaran Islam yang berkembang di Desa Ngadas diajarkan secara damai. Hal terpenting dari sikap masyarakat terhadap 
toleransi beragama. Jumlah pemeluk agama Islam di Desa Ngadas juga semakin hari semakin bertambah banyak. Pengislaman di Desa Ngadas dilakukan melalui proses perkawinan. Tidak ada pemaksaan yang dilakukan para agen Islam terhadap masyarakat. Unsur-unsur agama Islam lebih tepat dikatakan menyusup dalam kehidupan masyarakat Tengger Brang Kidul di Desa Ngadas. Agama dianggap sebagai suatu hal yang mengatur hubungan transendental yang berbeda dengan adat sehingga keduanya dapat berjalan beriringan. Peningkatan jumlah penduduk yang memeluk agama Islam menandakan kuatnya arus infiltrasi yang dilakukan oleh para agen. Para agen seolah mengkonstruksi suatu strategi yang dengan sadar ataupun tidak mampu menghegemoni masyarakat dengan memasukkan ideologi dan budaya mereka. Islam yang memiliki latar belakang budaya yang sangat berbeda dengan Indonesia (seperti bahasa dan tulisan Arab dan budaya jilbab) mampu diterima dalam masyarakat tradisional di Desa Ngadas.

\section{PENUTUP}

Kehidupan beragama masyarakat Tengger Brang Kidul di Desa Ngadas tidak dapat dilepaskan dari peran pemerintah yang berusaha untuk melakukan pendisiplinan agama. Hal tersebut menimbulkan suatu hubungan dialogis dan kompromistis antara masyarakat di Desa Ngadas dengan para kaum eksternalitas yang kemudian turut ambil bagian dalam membentuk manusia Tengger hari ini. Ideologi primordial yang dimiliki masyarakat Tengger Brang Kidul di Desa Ngadas tidak dapat dianggap sebagai isapan jempol belaka. Masyarakat meyakini agama yang mereka peluk saat ini bukan hanya bermakna sebagai warisan nenek moyang, tetapi merupakan keyakinan mereka terhadap nilai dan ajaran yang mereka miliki. Masyarakat mampu memahami dan mencintai inti ajaran agama mereka sebagai bagian dari diri dan kehidupan mereka. Dialektika kehidupan beragama yang dilakukan masyarakat setempat menghasilkan sebuah kehidupan harmonis yang patut untuk dijadikan teladan bagi daerah lain, terutama di daerah konflik.

\section{DAFTAR PUSTAKA}

Adrianto, Ambar. 2002. Komunitas Adat
Tengger di Desa Ngadisari, Kecamatan Sukapura, Kabupaten Probolinggo, Jawa Tmur. Jogjakarta: Dinas Kebudayaan DIY

Baso, Ahmad. 2005. Islam Pascakolonial: Perselingkuhan Agama, Kolonialisme, dan Liberalisme. Bandung: Mizan Pustaka.

Hefner, Robert W. 1999. "Geger Tengger: Perubahan Sosial dan Perkelahian Politik”. Cetakan I. Yogyakarta: LKiS.

Hefner, Robert W. 1985. "Hindu Javanese: Tengger Tradition and ISlam”. New Jersey: Princeton Univ.

Hidayattulah, Syarif. 2011. Studi Agama: Suatu Pengantar. Yogyakarta: Tiara Wacana.

Kholiludin, Tedi. 2009. Kuasa Negara Atas Agama: Politik Pengakuan, Diskursus Agama Resmi, dan Diskriminasi Hak Sipil. Semarang: RaSAIL.

Nashir, Haedar. 1999. Agama dan Krisis Kemanusiaan Modern. Yogyakarta: Pustaka Pelajar.

Rassers, W,H, et all. 2002. Ciwa Buddha Puja di Indonesia. Denpasar : Yayasan Dharma Sastra.

Sponberg, Alan., Helen Hardacre (ed). 1988. Maitreya: The Future Buddha. Cambridge: Cambridge University Press.

Sutarto, Ayu. 1997. Legenda Kasada dan Karo Orang Tengger Lumajang. Jakarta: UI.

Suamba, I,B,P. 2007. Siwa-Buddha di Indonesia : Ajaran dan Perkembangannya. Denpasar : Penerbit Widya Dharma.

Turner, Bryan S. 2013. Sosiologi Agama. Yogyakarta: Pustaka Pelajar.

Widyaprakosa, S. 1994. Masyarakat Tengger: Latar Belakang Daerah Taman Nasioal Bromo. Cetakan I. Yogyakarta: Kanisius.

Daftar Isian Potensi Desa Ngadas, Kecamatan Poncokusumo, Kabupaten Malang tahun 2001. 